\title{
ASSOCIATION OF GLUTATHIONE TRANSFERASE OMEGA POLYMORPHISMS WITH RISK AND SURVIVAL IN TRANSITIONAL CELL CARCINOMA OF URINARY BLADDER
}

\author{
Tatjana Đukić ${ }^{1}$, Ana Savić Radojević ${ }^{1}$, Dejan Dragičević \\ ${ }^{1}$ Institute of Medical and Clinical Biochemistry, Faculty of Medicine, University of Belgrade, Serbia \\ ${ }^{2}$ Clinic of urology, Clinical centre of Serbia, Faculty of Medicine, University of Belgrade, Serbia \\ Contact e-mail: tatjana.djukic@med.bg.ac.rs
}

Sažetak

Pušenje i profesionalna izloženost hemijskim kancerogenima su važan etiološki faktor u nastanku karcinoma prelaznog epitela mokraćne bešike. Citosolne glutation transferaze (GST) su superfamilija enzima koji štite ćelije katališući reakcije konjugacije elektrofilnih jedinjenja, uključujući kancerogene, sa glutationom. Opisano je nekoliko polimorfizama u okviru omega klase glutation transferaza (GSTO), a najpoznatiji su GSTO1*A140D (NCBI SNP ID: rs4925, 419 $\mathrm{Cu}$ A) i GSTO2*N142D (NCBI SNP ID: rs156697, 424 A u G). Osobe nosioci GSTO2*G/G genotipa imaju povećan rizik za nastanak karcinoma prelaznog epitela mokraćne bešike. Pored toga, nosioci GSTO ${ }^{\star} \mathrm{C} /$ $\mathrm{GSTO} 2^{\star} \mathrm{G}$ haplotipa su pod povećanim rizikom za nastanak karcinoma prelaznog epitela mokraćne bešike, a taj efekat je još izraženiji kod nosilaca varijantnog $G S T O 2^{*} G / G$ koji su istovremeno i pušači. Dalje, GSTO ${ }^{*}$ A/A i GSTO $2^{*}$ G/G genotipovi bi mogli imati prognostičku/farmakogenomsku ulogu kod bolesnika sa invazivnim karcinomom mokraćne bešike. Usled novootkrivene deglutationilišuće uloge GSTO1 sve je veći značaj koji omega klase glutation transferaza potencijalno ima u poremećaju redoks ravnoteže u karcinomu prelaznog epitela mokraćne bešike, a što može doprineti progresiji ovog karcinoma.

\section{Summary}

Exposure to chemical carcinogens, especially smoking and occupational exposure, is an etiologic factor for transitional cell carcinoma (TCC) of the urinary bladder. Cytosolic glutathione transferases (GSTs) are a superfamily of enzymes that protect normal cells by catalyzing conjugation reactions of electrophilic compounds, including carcinogens, to glutathione. Several types of allelic variations have been identified within GSTO class, with GSTO1*A140D (NCBI SNP ID: rs4925, 419 C to A) and GSTO2*N142D (NCBI SNP ID: rs156697, $424 \mathrm{~A}$ to $\mathrm{G}$ ) being the most common. Individuals with the GSTO2* $\mathrm{G} / \mathrm{G}$ genotype carry a higher risk for TCC. Our results indicate that GSTO $1^{\star} \mathrm{C} / \mathrm{GSTO}{ }^{\star} \mathrm{G}$ haplotype is associated with increased TCC risk, which is more pronounced in carriers of variant $\mathrm{GSTO} 2^{*} \mathrm{G} / \mathrm{G}$ combined with smoking. Furthermore, GSTO $1^{\star} \mathrm{A} / \mathrm{A}$ and GSTO $2^{*}$ G/G genotypes may have a prognostic/pharmacogenomic role in patients with muscle invasive TCC. Newly discovered deglutathionylase activity of GSTO1 suggests its potential important role in redox perturbations present in TCC, which might contribute to progression of TCC.
Bladder cancer is the fourth most common cancer in men and listed as the eighth leading cause of cancer-related deaths in men [1]. Approximately $90 \%$ of all bladder cancers are transitional cell carcinoma (TCC) [2], emphasizing the role of uroepithelial cells as the most vulnerable target of metabolic end products of different compounds, including carcinogens. Several environmental risk factors, including cigarette smoking and occupational exposure are recognized risk factors of bladder cancer [3].

Glutathione transferases (GSTs) are a superfamily of enzymes that catalyze the conjugation of glutathione
(GSH) to a wide range of chemical carcinogens, drugs and oxidative stress products. Seven cytosolic GST classes have been identified in humans: alpha, mu, pi, sigma, theta, zeta, and the most recently identified omega class [4]. Chloride Intracellular Channel proteins (CLIC 1-5) are structurally similar to GST and belong to the cytosolic GST family but they do not catalyze glutathione dependent reactions with substrates utilized by members of the other GST classes [5]. All seven classes of GST are prone to gene polymorphism [6].

The omega class GST (GSTO) shares only $20 \%$ amino acid sequence identity with the other GST class- 
es [7], with a range of catalytic activities typical only for this class and glutaredoxins but not other GST classes [6]. An important feature of both GSTO1 and GSTO2 isoenzymes is the presence of cysteine in their active site. In multiple alignments of GST sequences, Cys-32 in the active site aligns with tyrosine and serine residues that play significant catalytic roles in other GSTs [4]. Furthermore, the active site of GSTO1 is positioned in a wide crevice that can potentially accommodate large substrates, such as proteins [7]. Comparison of the literature data on the structures of GSTO1, GSTO2, CLIC2 and glutaredoxin detected several preserved features including their thioredoxin-like domains, and a glutathione (GSH) binding site where GSH can form a disulfide bond with a conserved active site cysteine residue [6]. In GSTO1-1, GSTO2-2 and glutaredoxin these structural similarities are the basis for their functional similarity pointed by their shared glutaredoxin (thioltransferase) activity. Beside thioltransferase activity, GSTO1-1 and GSTO2-2 also catalyze dehydroascorbate reductase reactions and the reduction of monomethylarsonic acid, an intermediate in the arsenic biotransformation pathway [4]. GSTO1-1 is also involved in the posttranslational modifications of inflammatory cytokine interleukine-1 $\beta$ (IL-1 $\beta$ ) and ryanodine receptor modulations. Cell and tissue distribution of GSTO1-1 and GSTO2-2 differ, but GSTO1-1 is expressed in almost every tissue [4].

The close structural and functional similarity suggested that GSTO1-1 and GSTO2-2 may also catalyze glutathionylation reactions. Glutathionylation (the formation of mixed disulfides between glutathione and protein thiols) during oxidative stress provides an efficient defense mechanism against irreversible oxidation since the disulfide bonds can be subsequently enzymatically reduced or "exchanged" [8]. Recent evidence clearly implied the regulatory role of glutathionylation in cell signaling $[9,10]$. Thus, it has been shown that glutathionylation influence several cellular processes including regulation of the cell cycle [11], apoptosis [12, 13, 14] and drug response in cancer [15]. Menon D. and Board PG. found that GSTO1-1 but not GSTO2-2 was capable of deglutathionylating a model peptide and that the activity was dependent on Cys 32 a residue that is also required for the glutaredoxin activity of GSTO1-1 (formerly termed thioltransferase) [6]. Although GSTO2 has $68 \%$ sequence identity with GSTO1 and a conserved cysteine residue in its active site [16], it did not exhibit any deglutathionylation activity [6]. Menon D. and Board PG. have previously reported significant differences in the substrate/activity profile of GSTO2-2 compared with GSTO1-1. GSTO2-2 has very high dehydroascorbate reductase activity compared to GSTO1-1 [6].
Since their first description, the omega class GSTs have been investigated in relation to a number of biologically significant pathways and clinical disorders including drug resistance [17], Alzheimer's Disease [18], Parkinson's disease [18], vascular dementia and stroke [19, 20] amyotrophic lateral sclerosis [21], the action of anti-inflammatory drugs [22], susceptibility to chronic obstructive pulmonary disease (COPD) $[23,24]$ and cancer $[25,26,27,28,29]$. However, the mechanism by which the Omega GSTs mediate their effects in these diverse settings has not been clear.

In humans, there are two actively transcribed genes termed GSTO1 and GSTO2 located on chromosome 10q 24.3. The GSTO1 gene has 6 exons and spans $12.5 \mathrm{~kb}$. The GSTO2 gene is approximately $7.5 \mathrm{~kb}$ downstream of GSTO1, it has also 6 exons and spans $24.5 \mathrm{~kb}$ [4]. Mukerjee B. et al. decribed 31 polymorphisms in GSTO1 and 66 polymorphisms of GSTO2 gene. Regarding the functional implication of those genetic variations in GSTO1 and GSTO2 genes, the most often investigated are single nucleotide polymorphisms (SNPs) of GSTO1, rs 4925 and GSTO2, rs 156697 [30]. A SNP (NCBI SNP ID: rs4925, 419 C to A) of GSTO1 was reported at nucleotide 419 causing an alanine to aspartate substitution in amino acid 140 (A140D, Ala140Asp) of exon 4. SNP of GSTO2 was found at nucleotide 424 causing an asparagine to aspartate substitution in amino acid 142 (N142D, Asn142Asp) of exon 4 (NCBI SNP ID: rs156697, 424 A to G) [26]. Furthermore, Marahatta SB. et al. [31] have shown that GSTO1*A140D polymorphism could play an important role as a risk factor for the development of hepatocellular carcinoma, cholangiocarcinoma and breast cancer, while GSTO2 polymorphism rs156697, has been evaluated in terms of risk of various malignancies [26, 31, 32].

Since GST omega class is involved in arsenic metabolism [4], several studies conducted in Asian population looked into association between GSTO1 and GSTO2 polymorphisms and arsenic exposure on bladder cancer risk [26, 34]. Thus, Wang et al. found a significant joint effect of cigarette smoking, alcohol consumption, arsenic and occupational exposures and GSTO1/GSTO2 diplotypes on risk of urothelial cancer (UC) [26]. Lesseur C. et al. observed a main effect of the GSTO2 Asn142Asp variant on bladder cancer risk that was unrelated to arsenic exposure [35]. Similarly, Hsu LI. et al. found a borderline significant increase risk of UC in GSTO2 homozygous variant carriers in southwestern Taiwan [36]. Contrary to those results, a case-control study of Chung CJ. et al. in the same non-endemic arsenic area (Taipei), found a decreased risk of UC in homozygous variant carriers of GSTO2 Asn142Asp along with higher levels of monomethylarsonic acid (MMA\%) in urine in wild 
type individuals [34]. In another study, no association was observed with urinary arsenic profiles and GSTO2 Asn142Asp genotype in a Chinese population chronically exposed to arsenic [37].

This has motivated us to explore the association of common GST omega polymorphisms with the risk of bladder cancer, as well as, their joint effect with cigarette smoking and occupational exposure. We found that carriers of variant $\mathrm{GSTO} 2^{*} \mathrm{G} / \mathrm{G}$ genotype were at increased risk for the development of TCC, while GSTO1 rs4925 polymorphism was not significantly associated with TCC risk. According to smoking status, smokers with GSTO $2^{\star} \mathrm{G} / \mathrm{G}$ genotype had significantly higher risk of TCC of urinary bladder $(\mathrm{OR}=4.3, \mathrm{p}=0.003)$ compared to wild type carriers with no smoking history. We further assessed the effects of GSTO1/GSTO2 haplotypes on TCC risk, based on the linkage disequilibrium found for GSTO1 (rs4925) and GSTO2 (rs156697). The study subjects with $\mathrm{GSTO}{ }^{*} \mathrm{C} / \mathrm{GSTO} 2^{*} \mathrm{G}$ (GSTO1 wild type/ GSTO2 variant) haplotype were at the highest risk for the development of transitional cell carcinoma of urinary bladder $(\mathrm{OR}=2.8, \mathrm{p}=0.002)$ [38].

Our data on increased risk in carriers of variant GSTO2 genotype are concordant with already published results of Wang YH. [26] and Chung CJ. [34], but the explanation about which functions of this enzyme account for this increased risk is lacking. It should be noted that GSTO1 glutathyionylation activity is strongly influenced by GSTO1 polymorphism. Kinetic analysis of the deglutathionylation reaction with the glutathionylated peptide revealed that the A140 allelic variant of GSTO1 has a significantly higher specific activity than the D140 variant. In contrast the D140 variant has a higher activity in the forward glutathionylation reaction with glutathione thiyl radicals as a substrate [6]. Since glutathionylation can influence protein structure and function, the difference in activity and the potential difference in protein specificity between the allelic variants of GSTO1 could provide a plausible mechanism to explain the associations between this genetic polymorphism and a range of disorders [6]. It might be speculated that the presence of $\mathrm{GSTO}{ }^{*}{ }^{*} \mathrm{~A} 140$ allelic variant might also favor deglutathionylation of protooncogenic proteins involved in the promotion of bladder tumors and thus contribute to overall risk in carriers of $\mathrm{GSTO} 1{ }^{\star} \mathrm{C} / \mathrm{GSTO} 2{ }^{\star} \mathrm{G}$ (GSTO1 wild type/GSTO2 variant) haplotype. Among oncogenic proteins which are subject to regulation by these molecular mechanism, is antiapoptotic GSTP1 enzyme, with well-defined role in TCC promotion and progression $[39,40]$.

GSTO2 is enzyme with the most prominent dehydroascorbate reductase (DHAR) activity in humans with an important role in regeneration of dehydroascorbate [16]. Moreover, it was speculated that DHAR activity of
GSTO2 might be influenced by ${ }^{*} \mathrm{~N} 142 \mathrm{D}$ polymorphism [41]. Therefore, it may be speculated that low enzyme activity in subjects with both variant GSTO2 alleles would presumably result in deficient DHAR activity and lower ascorbic acid level in the bladder. In the view of the role of oxidative stress in the biology of urothelial tumors [39], altered activity of GSTO2 protein might result in inter-individual differences in capacity to scavenge and detoxify reactive species produced by smoking or occupational exposure in TCC patients. Indeed, we found that smokers carriers of GSTO2 ${ }^{\star} \mathrm{G} / \mathrm{G}$ genotype were, at approximately 4 -fold increased TCC risk. It is important to note that in addition to its antioxidant role, ascorbic acid (vitamin C) is also involved in regulation of hypoxia-inducible factor (HIF)-1, a transcription factor that regulates many genes responsible for tumor growth, energy metabolism and apoptosis [42]. In that context, recent data speculates that vitamin C-dependent inhibition of the HIF pathway may provide additional approach for controlling tumor progression and inflammation [43].

Taken together, the presence of $\mathrm{GSTO}^{\star}{ }^{\star} \mathrm{C} /$ GSTO2 ${ }^{\star} \mathrm{G}$ (GSTO1 wild type/GSTO2 variant) haplotype, comprising high deglutathionylation and low DHAR activity, might underlie the increased TCC risk among our patients.

We also analyzed the effect of GSTO1 and GSTO2 polymorphisms on predicting mortality in the group of patients with muscle invasive TCC of urinary bladder, as well as, the association of these two GSTO1 and GSTO2 polymorphisms with the survival of patients with muscle invasive TCC, together with the genotype modifying effect on chemotherapy. GSTO1 Asp140Asp and GSTO2 Asp142Asp genotypes were independent predictors of a higher risk of death among bladder cancer patients (HR $=2.9, \mathrm{P}=0.022 ; \mathrm{HR}=3.9, \mathrm{p}=0.001$; respectively) and significantly influenced the overall survival. We found that only GSTO2 polymorphism rs156697 showed a significant effect on the survival in the subgroup of patients who received chemotherapy $(\mathrm{p}=0.006)$.

To conclude, the glutathione transferase omega class have a specific range of enzymatic activities compared with other GSTs, probably due to the presence of a cysteine residue in the active site. Since GSTO1-1 is widely expressed in many tissues, it appears to be capable of playing a major role in the glutathionylation cycle. Recent experiments have revealed the contribution of GSTO1-1 to the deglutaththionylation of proteins. Genetic polymorphism in the GSTO1 and GSTO2 genes may influence the risk for development and progression of various set of nonmalignant and malignant diseases. 


\section{References}

1. Sexton WJ, Wiegand LR, Correa JJ, Politis C, Dickinson SI, Kang LC. Bladder cancer: A review of non-muscle-invasive disease. Cancer Control. 2010;17:256-268.

2. Matic M, Pekmezovic T, Djukic T, Mimic-Oka J, Dragicevic D, Krivic B, Suvakov S, Savic-Radojevic A, Pljesa-Ercegovac M, Tulic C, Coric V, Simic T. GSTA1, GSTM1, GSTP1, and GSTT1 polymorphisms and susceptibility to smoking-related bladder cancer: a case-control study. Urol Oncol. 2013;31(7):1184-1192.

3. Hayes JD, Flanagan JU, Jowsey IR. Glutathione transferases. Annu Rev Pharmacol Toxicol. 2005;45:51-88.

4. Whitbread AK, Masoumi A, Tetlow N, Schmuck E, Coggan M, Board PG. Characterization of the omega class of glutathione transferases. Methods Enzymol. 2005;401:78-99.

5. Dulhunty A, Gage P, Curtis S, Chelvanayagam G, Board P. The glutathione transferase structural family includes a nuclear chloride channel and a ryanodine receptor calcium release channel modulator. J Biol Chem. 2001;276(5):3319-3323.

6. Menon D, Board PG. A role for glutathione transferase Omega 1 (GSTO1-1) in the glutathionylation cycle. J Biol Chem. 2013;288(36):25769-25779.

7. Board PG, Coggan M, Chelvanayagam G, Easteal S, Jermiin LS, Schulte GK, Danley DE, Hoth LR, Griffor MC, Kamath AV, Rosner MH, Chrunyk BA, Perregaux DE, Gabel CA, Geoghegan KF, Pandit J. Identification, characterization, and crystal structure of the Omega class glutathione transferases. J Biol Chem. 2000;275(32):24798-24806.

8. Cooper AJ, Pinto JT and Callery PS. Reversible and irreversible protein glutathionylation: biological and clinical aspects. Expert Opin Drug Metab Toxicol. 2011;7:891910.

9. Dalle-Donne I, Rossi R, Colombo G, Giustarini D and Milzani A. Protein S- glutathionylation: a regulatory device from bacteria to humans. Trends Biochem Sci. 2009;34:85- 96.

10. Pastore A and Piemonte, F. S-Glutathionylation signaling in cell biology: progress and prospects. Eur J Pharm Sci. 2012;46:279-292.

11. Jarry A, Charrier L, Bou-Hanna C, Devilder MC, Crussaire V, Denis MG, Vallette G and Laboisse CL. Position in cell cycle controls the sensitivity of colon cancer cells to nitric oxide-dependent programmed cell death. Cancer Res. 2004;64:4227-4234.

12. Bedhomme M, Adamo M, Marchand CH., Couturier J, Rouhier N, Lemaire SD, Zaffagnini M and Trost P. Glutathionylation of cytosolic glyceraldehyde-3- phosphate dehydrogenase from the model plant Arabidopsis thaliana is reversed by both glutaredoxins and thioredoxins in vitro. Biochem J. 2012;445:337-347.

13. Anathy V, Roberson E, Cunniff B, Nolin JD, Hoffman S, Spiess P, Guala AS, Lahue KG, Goldman D, Flemer S, van der Vliet A, Heintz NH, Budd RC, Tew KD and Janssen-Heininger YM. Oxidative processing of latent Fas in the endoplasmic reticulum controls the strength of apoptosis. Mol Cell Biol. 2012;32:3464-3478.
14. Allen EM and Mieyal JJ. Protein-thiol oxidation and cell death: regulatory role of glutaredoxins. Antioxid Redox Signal. 2012;17:1748-1763.

15. Lei K, Townsend DM and Tew KD. Protein cysteine sulfinic acid reductase (sulfiredoxin) as a regulator of cell proliferation and drug response. Oncogene 2008;27: 4877-4887.

16. Zhou H, Brock J, Liu D, Board PG and Oakley AJ. Structural insights into the dehydroascorbate reductase activity of human omega-class glutathione transferases. J Mol Biol. 2015;420:190-203.

17. Kodym R, Calkins $P$ and Story $M$. The cloning and characterization of a new stress response protein. A mammalian member of a family of theta class glutathione s-transferase- like proteins. J Biol Chem 1999;274:5131-5137.

18. Allen M, Zou F, Chai HS, Younkin CS, Miles R, et al. Glutathione S-transferase omega genes in Alzheimer and Parkinson disease risk, age-at-diagnosis and brain gene expression: an association study with mechanistic implications. Mol Neurodegener. 2012;7:13.

19. Kolsch H, Larionov S, Dedeck O, Orantes M, Birkenmeier G, Griffin WS and Thal DR. Association of the Glutathione S-transferase Omega-1 Ala140Asp Polymorphism With Cerebrovascular Atherosclerosis and Plaque-Associated Interleukin-1\{alpha\} Expression. Stroke 2007;38:28472850.

20. Kolsch H, Linnebank M, Lutjohann D, Jessen F, Wullner U, Harbrecht U, Thelen KM, Kreis M, Hentschel F, Schulz A, von Bergmann K, Maier W and Heun R. Polymorphisms in glutathione S-transferase omega-1 and $\mathrm{AD}$, vascular dementia, and stroke. Neurology 2004;63:2255-2260.

21. van de Giessen E, Fogh I, Gopinath S, Smith B, Hu X, Powell J, Andersen P, Nicholson G, Al Chalabi A. and Shaw CE. Association study on glutathione S- transferase omega 1 and 2 and familial ALS. Amyotroph Lateral Scler.2008;9:81-84.

22. Laliberte RE, Perregaux DG, Hoth LR, Rosner PJ, Jordan CK, Peese KM, Eggler JF, Dombroski MA, Geoghegan KF. and Gabel CA. Glutathione s- transferase omega 1-1 is a target of cytokine release inhibitory drugs and may be responsible for their effect on interleukin-1beta posttranslational processing. J Biol Chem 2003;278:16567-16578.

23. Harju TH, Peltoniemi MJ, Rytila PH, Soini Y, Salmenkivi KM, Board PG, Ruddock LW and Kinnula VL. Glutathione S-transferase omega in the lung and sputum supernatants of COPD patients. Respir Res. 2007;8: 48.

24. Yanbaeva DG, Wouters EF, Dentener, MA, Spruit MA. and Reynaert NL. Association of glutathione-S-transferase omega haplotypes with susceptibility to chronic obstructive pulmonary disease. Free Radic Res. 2009;43:738-743.

25. Pongstaporn W, Pakakasama S, Sanguansin S, Hongeng S. and Petmitr S. Polymorphism of glutathione S-transferase Omega gene: association with risk of childhood acute lymphoblastic leukemia. J Cancer Res Clin Oncol. 2009;135:673-678.

26. Pongstaporn W, Rochanawutanon M, Wilailak S, Linasamita V, Weerakiat S. and Petmitr S. Genetic alterations in chromosome 10q24.3 and glutathione S-transferase omega 2 gene polymorphism in ovarian cancer. J Exp Clin Cancer Res. 2006;25:107-114. 
27. Wang YH, Yeh SD, Shen $\mathrm{KH}$, Shen $\mathrm{CH}$, Juang GD, Hsu LI, Chiou HY. and Chen CJ. A significantly joint effect between arsenic and occupational exposures and risk genotypes/diplotypes of CYP2E1, GSTO1 and GSTO2 on risk of urothelial carcinoma. Toxicol Appl Pharmacol. 2009;241:111-118.

28. Andonova IE, Justenhoven C, Winter S, Hamann U, Baisch C, Rabstein S, Spickenheuer A, Harth V, Pesch B, Bruning T, Ko YD, Ganev V. and Brauch H. No evidence for glutathione S-transferases GSTA2, GSTM2, GSTO1, GSTO2, and GSTZ1 in breast cancer risk. Breast Cancer Res Treat. 2010;121:497-502.

29. Masoudi M, Saadat I, Omidvari S. and Saadat M. Genetic polymorphisms of GSTO2, GSTM1, and GSTT1 and risk of gastric cancer. Mol Biol Rep 2009;36:781-784.

30. Mukherjee B, Salavaggione OE, Pelleymounter LL, Moon I, Eckloff BW, Schaid DJ, Wieben ED, Weinshilboum RM. Glutathione S-transferase omega 1 and omega 2 pharmacogenomics. Drug Metab Dispos. 2006;34(7):1237-1246.

31. Marahatta SB, Punyarit P, Bhudisawasdi V, Paupairoj A, Wongkham S, Petmitr S. Polymorphism of glutathione S-transferase omega gene and risk of cancer. Cancer Lett. 2006;236(2):276-81.

32. Sanguansin S, Petmitr S, O-Charoenrat P, Pongstaporn W. Association of glutathione S-transferase omega gene polymorphisms with progression of head and neck cancer. Mol Biol Rep. 2012;39(12):10915-10920.

33. Masoudi M, Saadat I, Omidvari S, Saadat M. Association between N142D genetic polymorphism of GSTO2 and susceptibility to colorectal cancer. Mol Biol Rep. 2011; 38(7):4309-4313.

34. Chung CJ, Pu YS, Su CT, Huang CY, Hsueh YM. Gene polymorphisms of glutathione S-transferase omega 1 and 2 , urinary arsenic methylation profile and urothelial carcinoma. Sci Total Environ. $2011 ; 409(3): 465-470$.

35. Lesseur C, Gilbert-Diamond D, Andrew AS, Ekstrom RM, Li Z, Kelsey KT, Marsit CJ, Karagas MR. A case-control study of polymorphisms in xenobiotic and arsenic metabolism genes and arsenic-related bladder cancer in New Hampshire. Toxicol Lett. 2012;210(1):100-106.
36. Hsu LI, Chen WP, Yang TY, Chen YH, Lo WC, Wang YH, Liao YT, Hsueh YM, Chiou HY, Wu MM, Chen CJ. Genetic polymorphisms in glutathione S-transferase (GST) superfamily and risk of arsenic-induced urothelial carcinoma in residents of southwestern Taiwan. J Biomed Sci. 2011;18:51.

37. Xu Y, Li X, Zheng Q, Wang H, Wang Y, Sun G. Lack of association of glutathione-S-transferase omega 1(A140D) and omega 2 (N142D) gene polymorphisms with urinary arsenic profile and oxidative stress status in arsenic-exposed population. Mutat Res. 2009;679(1-2):44-49.

38. Djukic T, Simic T, Radic T, Matic M, Pljesa-Ercegovac M, Suvakov S, Coric V, Pekmezovic T, Novakovic I, Dragicevic D, Savic-Radojevic A. GSTO $1^{\star} \mathrm{C} / \mathrm{GSTO} 2{ }^{\star} \mathrm{G}$ haplotype is associated with risk of transitional cell carcinoma of urinary bladder. Int Urol Nephrol. 2015;47(4):625-630.

39. Savic-Radojevic A, Mimic-Oka J, Pljesa-Ercegovac M, Opacic M, Dragicevic D, Kravic T, Djokic M, Micic S, Simic T. Glutathione S-transferase-P1 expression correlates with increased antioxidant capacity in transitional cell carcinoma of urinary bladder. Eur Urol. 2007;52(2):470-477.

40. Pljesa-Ercegovac M, Savic-Radojevic A, Dragicevic D, Mimic-Oka J, Matic M, Sasic T, Pekmezovic T, Vuksanovic A, Simic T. Enhanced GSTP1 expression in transitional cell carcinoma of urinary bladder is associated with altered apoptotic pathways. Urol Oncol. 2011;29(1):70-77.

41. Piacentini S, Monaci PM, Polimanti R, Manfellotto D, Fuciarelli M. GSTO2*N142D gene polymorphism associated with hypothyroidism in Italian patients. Mol Biol Rep. 2013; 40:1967-1971.

42. Tian W, Wang Y, Xu Y, Guo X, Wang B, Sun L, Liu L, Cui F, Zhuang Q, Bao X, Schley G, Chung TL, Laslett AL, Willam C, Qin B, Maxwell PH, Esteban MA. The hypoxia-inducible factor renders cancer cells more sensitive to vitamin C-induced toxicity. J Biol Chem. 2014; 289(6):3339-3351.

43. Traber MG, Stevens JF. Vitamins C and E: beneficial effects from a mechanistic perspective. Free Radic Biol Med. 2011;51(5):1000-1013 